\title{
Makna Simbol Bentuk Dan Seni Hias Pada Rumah Bugis Sulawesi Selatan
}

\author{
Pangeran Paita Yunus \\ Universitas Negeri Makassar \\ Jalan Traktor IV No. 31 Komplek PU Malengkeri Parangtambung \\ Makassar, 90222
}

\begin{abstract}
The cosmologic view of the Buginese tribe assumes that this macrocosmos (the universe) is arranged into three levels: Boting langi' (the upper world), Ale kawa (the middle world), Uri' Li'yu' (the under world). As the centre of the three parts of this universe is Boting Langi (the highest sky), the place where Dewata seuwae (God) stay down. This view is represented in the King's Palace/traditional house building seen as the microcosmos. So, the King's palace of the Buginese is devided also into three levels (stacks), those are: Rekkeang (top floor) viewed as the head of the human being, Alle bola (the body of the house) viewed as the body, and Awa bola (space underneath of the house) viewed as the leg of the human being. The three parts are centered at Posi' bola or the house navel. This research tries to answer the problems: 1) whether the meaning form of the King's Palace of the Buginese based on cosmology, and 2) how the simbol meaning of decorative art at the King's Palace of the Buginese is. To identify and comprehend the meaning of decorative art on the King's Palace of the Buginese, it is done through hermeneutic theory by Gadamer and the simbol meaning theory by Victor Turner. This research gives description that the happening of structural change and the style of decorated art at the kings' palace of the Buginese of South Sulawesi, beside having much influence from the art of Dong-son and Chou Tua style, the decorated art at the Buginese tribe also got influence from Hinduism and Islam. In addition, the change of the art style is decided also by the one who has power in the society, either in the politic side or in the religion or culture. In this case, the existence of art style variation is caused by the existence of the levelling and groupping of the society.
\end{abstract}

Keyword: Decorated art, Buginese tribe, Shape Simbol.

\section{PENDAHULUAN}

Rumah tradisional sebagai salah satu modal kebudayaan tumbuh dan berkembang bersamaan dengan pertumbuhan suatu bangsa. Oleh karena itu, kehadiran sebuah rumah tradisional merupakan salah satu identitas dari komunitas pendukung kebudayaan. Dalam rumah tradisional sebagai sebuah karya cipta manusia, terkandung secara terpadu tiga wujud kebudayaan, yakni: 1. Wujud kebudayaan sebagai suatu kompleks aktivitas dari ideide, gagasan, nilai-nilai, norma-norma, peraturan dan sebagainya; 2. Wujud kebudayaan sebagai suatu kompleks aktivitas kelakuan berpola dari manusia dalam masyarakat; 3. Wujud kebudayaan sebagai benda-benda hasil karya manusia ${ }^{1}$.

Dalam kenyataan kehidupan masyarakat ketiga wujud dari kebudayaan tersebut di atas, tentu tidak terpisah satu 
dengan lain. Kebudayaan ide dan adat istiadat mengatur dan memberi arah kepada perbuatan dan karya manusia. Pikiranpikiran dan ide-ide maupun perbuatan dan karya manusia, menghasilkan benda-benda kebudayaan fisiknya. Sebaliknya, menurut Koentjaraningrat, kebudayaan fisik itu membentuk suatu lingkungan hidup tertentu yang makin lama makin menjauhkan manusia dari lingkungan alamiahnya, sehingga mempengaruhi pula pola-pola perbuatannya, bahkan juga mempengaruhi cara berpikirnya ${ }^{2}$. Jikalau wujud-wujud kebudayaan itu dihayati dan diamalkan, maka lahirlah rasa bangga dan rasa cinta terhadap karya itu. Salah satu wujud yang dimaksud adalah terdapatnya berbagai macam simbol pada rumah tradisional di Sulawesi Selatan.

Rumah tradisional merupakan karya yang tumbuh dan berkembang di bawah pengaruh tradisi, aktivitas sosial budaya, dan perilaku masyarakat ${ }^{3}$. Oleh sebab itu, sebuah karya rumah seperti rumah Bugis Sulawesi Selatan semestinya juga sebagai cerminan budaya yang mempunyai makna dan fungsi sebagaimana mestinya.

Rumah atau istana dengan berbagai macam simbol yang melekat pada bangunan, lebih dari sekedar tempat tinggal melainkan merupakan bangunan teratur berlambang yang menunjukkan sejumlah ide penting dan hal-hal yang berkaitan dengan kebudayaan ${ }^{4}$. Kebudayaan itu sendiri adalah kesatuan dari gagasan-gagasan, simbol-simbol dan lain-lain yang mendasari hasil karya dan perilaku manusia, sehingga tidaklah berlebihan jika dikatakan bahwa manusia sebagai homo simbolicum ${ }^{5}$. Dengan demikian, karya budaya manusia penuh simbolisme sesuai dengan paham yang mengarahkan pada pola-pola kehidupan sosialnya.
Simbol-simbol yang terdapat pada masyarakat Bugis hanya dapat dipahami oleh anggota masyarakat pendukungnya berdasarkan tata nilai yang berlaku dalam sistem sosialnya. Hal ini sesuai pendapat Clifford Geertz yang mendefinisikan kebudayaan sebagai suatu sistem keteraturan dari makna dan simbol-simbol, yang dengan makna dan simbol tersebut individu-individu mendefinisikan dunia mereka, mengekspresikan perasaan-perasaan mereka, dan membuat penilaian mereka ${ }^{6}$.

Namun demikian, sejauhmana kebudayaan daerah dapat dikenal dan dicintai masyarakat pendukungnya, adalah hal yang membutuhkan analisis untuk menunjukkan identitas bangsa yang berkepribadian. Budaya daerah yang bersifat nasional perlu diidentifikasi demi pelestariannya, demikian halnya dengan rumah Bugis Sulawesi Selatan sebagai salah satu aset lokal yang perlu dipertahankan eksistensinya, bahkan dilestarikan sebagai salah satu kearifan lokal masyarakat pendukungnya dan warisan yang dapat memperkaya seni budaya di tanah air.

Teori hermeneutik model Gadamer ${ }^{7}$ dan teori penafsiran Victor Turner ${ }^{8}$, dipandang tepat digunakan untuk menganalisis makna simbolis pada seni hias dan struktur bentuk rumah Bugis. Analisis hermeneutik digunakan untuk mempertajam dalam menjawab permasalahan dalam penelitian ini. Pendekatan sejarah seni digunakan untuk menelusuri keberadaan kearifan lokal dalam seni hias rumah Bugis. Dalam mengkaji seni hias dimaksud sebagai artefak digunakan analisis sinkronis dan diakronis ${ }^{9}$. Dalam analisis sinkronis, seni hias diamati sebagai sistem yang terstruktur. Sistem ini terdiri atas fungsi dan fakta fisik, berupa tanda-tanda visual, di antaranya bentuk, warna, dan ukur- 
an. Struktur memusatkan perhatiannya pada kesatuan yang mencakup unsur-unsur serta hubungan pengaruh mempengaruhi dalam situasi tertentu. Penggalian bagaimana terjadinya perkembangan seni hias di masa lampau dan mengarahkan penelitian ke arah ditemukannya kearifan lokal dalam seni hias Bugis, dilakukan dengan menggunakan analisis diakronik ${ }^{10}$. Analisis diakronik dipahami sebagai studi tentang proses ${ }^{11}$. Model analisis diakronis yang menawarkan bukan saja sebuah struktur dan fungsinya, melainkan suatu gerak dalam waktu dari kejadian-kejadian yang kongkret harus menjadi tujuan utama dari penulisan sejarah. Dengan kata lain, model diakronis adalah sebuah model dinamis ${ }^{12}$.

Teknik analisis datanya adalah analisis nonstatistik atau analisis kualitatif. Dalam penelitian ini diterapkan analisis interaktif yang dikemukakan oleh Miles dan Huberman ${ }^{13}$. Model analisis interaktif ini ada tiga komponen yang saling berkaitan dan berinteraksi satu sama lain, yang tidak bisa dipisahkan. Ketiganya adalah (1) reduksi data, (2) sajian/display data, dan (3) penarikan kesimpulan. Reduksi data sebagai proses penyeleksian data yang terkumpul berdasarkan dengan objek penelitian.

\section{PEMBAHASAN}

\section{Makna Bentuk Rumah Bugis Berdasar- kan Kosmologi}

Pandangan kosmologis suku Bugis mengenal adanya tiga macam pengklasifikasian, yakni klasifikasi pelapisan Dunia (dunia atas, dunia tengah, dan dunia bawah), klasifikasi struktur rumah tradisionalnya (kepala, badan dan kaki rumah), dan klasifikasi empat penjuru mata angin (utara, selatan, barat dan timur). Empat penjuru mata angin ini mewakili pengertian sulapa eppa wala suji (segi empat belah ketupat), Segi empat belah ketupat ditafsirkan sebagai model dari kosmos. Model kosmos dihubungkan dengan adanya empat sarwa alam, yaitu: udara, air, api, dan tanah yang tidak terpisahkan dari kehidupan manusia. Lebih lanjut segi empat diproyeksikan kepada asas kehidupan manusia yang terdiri atas empat juga, yakni:

1. Azas kehidupan tentang eksistensi kelahiran manusia

2. Azas kehidupan tentang eksistensi kehadiran manusia

3. Azas kehidupan tentang eksistensi pengabdian manusia dalam makrokosmos dan,

4. Azas kehidupan tentang kematian manusia $^{14}$.

Dengan kata lain, angka empat merupakan falsafah hidup suku Bugis yang tersimpul dalam empat asas kehidupan tersebut. Model segi eppa wala suji sebagai model makrokosmos harus diikuti sebagai model dari mikrokosmos. Empat asas kehidupan manusia Bugis terpancar pula pada model rumah tradisionalnya yang biasa disebut bola ugi. bola ugi sebagai rumah keturunan keluarga, rumah adat, tempat pemeliharaan dan pembinaan sistem religi/kepercayaan dan penyelenggaraan aturan-aturan agama. Bola ugi juga berfungsi sebagai pusat pemerintahan ( $\mathrm{Sa}$ oraja).

Dari konsep di atas, mengilhami bentuk struktur bola ugi (rumah Bugis) senantiasa mengikuti model makrokosmos yang secara konseptual harus mengikuti model persegi empat. Kemudian model bola ugi ini mengikuti pula struktur makrokosmos yang terdiri atas tiga tingkatan atau lapisan 
dunia yakni: bagian atas (rakkeang), bagian tengah (alle bola), dan bagian bawah (awa bola).

Dalam mitologi suku Bugis, dikatakan bahwa sistem upacara yang dilakukan oleh kelompok-kelompok atau anggota masyarakat (individu) tidak boleh bertentangan dengan prinsip-prinsip menurut sistem kepercayaan. Dalam sistem kepercayaan attauriolong, dikenal adanya tiga unsur yang disembah dan diberi upacara. Pertama, mereka percaya kepada dewa-dewa yang dikepalai oleh Dewata Seuwae. Kedua, mereka percaya kepada roh nenek moyang. Ketiga, mereka percaya kepada kekuatan gaib.

Bagian-bagian ini menurut konsep mitologi Bugis adalah:

\section{a. Bagian Atas Rumah (Rakkeang)}

Suku Bugis Sulawesi Selatan percaya bahwa bahwa Dewata Seuwae yang dianggapnya sebagai dewa tertinggi, pencipta alam raya ini. Dewata Seuwae menciptakan segala-galanya, sebagaimana wujud alam sekarang ini dan percaya kepada dewa-dewa yang diberi amanah untuk menjaga dan memelihara ciptaan Dewata Seuwae dan mengawasi berjalannya tata tertib alam raya.

Dalam sistem upacara, Dewata Seuwae beserta dewa boting langi', dianggap bersemayam di bagian langit, maka upacara persembahan kepadanya berlokasi di bagian badan. Rumah (alle bola), namun sesajiannya dipersembahkan ke bagian atas rumah (rakkeang) yang dianggap sebagai dunia atas atau sebagai bersemayamnya Dewa boting langi'. Kegiatan ini biasa disebut massorong riase (penyembahan ke atas bagi dewa yang berada di langit). Ini pula yang menyebabkan suku Bugis menyimpan padi dan benda-benda pusa- ka milik keluarga, yang dianggap bernilai sakral pada bagian ini, karena rakkeang (loteng) rumah bagi suku Bugis dianggap sebagai ruang suci.

\section{b. Bagian Badan Rumah (Alle bola)}

Pada dasarnya, rumah Bugis mempunyai tiga ruangan. Masing-masing ruang memiliki fungsinya masing-masing, yakni: ruang depan (lontang ri saliweng), ruang tengah (lontang ri tenggah), dan ruang belakang (lontang ri laleng).

Secara struktural, bagian ini merupakan bagian rumah yang paling banyak digunakan untuk melakukan aktivitas-aktivitas kekeluargaan. Bagian ini merupakan tempat segala aktivitas upacara tradisional dilakukan. Upacara perkawinan, inisiasi kelahiran sampai kematian, dan lain sebagainya. Dalam konsep mistis Bugis, ruangan ini dipandang sebagai bagian penyembahan dewa mallino dan dianggap sebagai tempat bertemunya dunia atas dan dunia bawah atau antara boting langi dengan uri liyu. Oleh karena itu, bagian ini dianggap mewakili pengertian-pengertian kerukunan, keharmonisan susunan alam, keseimbangan perintah dan larangan.

\section{c. Bagian Bawah Rumah (Awa bola)}

Bagian ini menurut pandangan mitologi Bugis, sebagai tempat bersemayamnya Dewa Uwae dan dianggap sebagai dunia bawah dan tempat segala sesuatu yang kurang baik dan tidak suci. Tempat ini berada di bawah (di bawah air), maka penyembahan sesajen dilakukan di bawah kolong rumah atau di sungai. Kegiatan ini disebut dengan massorong ri awa sokko patanrupa (persembahan kepada Dewa Uwae berupa nasi ketan dalam empat warna) sebagai simbol dari sarwa alam, yakni: air, udara, tanah, dan api. 
Dari analisis tentang makna struktur rumah Bugis berdasarkan mitologi (kosmologi), yakni rumah tradisional Bugis menjadi pusat dari letak serta tempat upacara ritual keagamaan. Rumah Bugis menjadi pusar lintang Timur-Barat dan bujur UtaraSelatan. Dengan kata lain, rumah Bugis sebagai pusat dari kosmos bagi manusia.

Dari struktur rumah tradisional Bugis yang terdiri atas tiga lapisan/susun, yaitu bagian atas disebut boting Iangi', tengah disebut alle kawa dan bagian bawah disebut uri liyu. Berarti rumah tradisional Bugis dianggap sama dengan alam raya ini (makrokosmos) yang terdiri atas tiga bagian, yakni bagian dunia atas, dunia tengah, dan dunia bawah. Dunia atas berada di langit, dunia tengah berada di bumi dan dunia bawah berada di bawah air. Sehubungan dengan sistem kepercayaan attauriolong yang mempercayai adanya tiga unsur, yaitu: Dewata Seuwae yang membawahi tiga dewa (boting langi', malino, dan uwae), roh para leluhur dan kekuatan gaib. Dengan demikian, rumah Bugis beserta unsur dalam masing-masing struktur, termasuk seni hiasnya merupakan simbol kosmos menurut jalur vertikal yang berhubungan dengan ajaran teologis atas dasar kepercayaan ketiga unsur kosmos tersebut. Tiga unsur itu senantiasa harus diberi sesajian dan penyembahan. Dengan kata lain, secara rutin diadakan upacara terhadapnya, agar senantiasa juga terjalin hubungan baik antara manusia dengan para penguasa tersebut.

\section{Makna Simbol Seni Hias Pada Rumah Bugis}

Bagian ini akan dikemukakan proses pemaknaan seni hias yang terdapat pada rumah tradisional Bugis berdasarkan pembagian tingkatan atau susunan rumah Bugis dengan tetap mengacu pada pemaknaan berdasarkan struktur bangunan.

\section{a. Makna Seni Hias Istana Bagian Atas}

Motif seni hias yang terdapat pada bagian atas rumah yang dibatasi pada mahkota atap atau biasa yang disebut anjong. Hiasan-hiasan anjong ini pada dasarnya dapat diklasifikasikan menjadi dua, yakni:

1) Seni hias fauna yang dijumpai dalam bentuk ayam jantan, naga, dan kepala kerbau.

2) Seni hias flora, dijumpai dalam bentuk bunga yang biasa disebut bunga parenreng, buah nenas, rebung, dan lain-lain.

\section{(a) Motif Hias Ayam Jantan}

Motif hias Ayam Jantan banyak ditemukan pada rumah tradisional Bugis. Ayam bagi suku Bugis di samping sebagai hewan piaraan juga menurut mereka memiliki makna-makna simbolis.

Hiasan ini biasanya ditempatkan pada bagian atap atau pada puncak bubungan rumah (anjong). Posisi hiasan mengikuti arah hadap rumah. Pola hias ini memiliki beberapa bentuk variasi, di antaranya:

(1) Bentuk ayam utuh (ada kepala, badan, dan kaki ayam).

(2) Bentuk beberapa bagian ayam saja (kepala dan jambul).

Motif ayam jantan dalam bahasa Bugis ditemukan pada istana Raja Sidenreng Kabupaten Sidenreng Rappang disebut manu' yang berarti baik. Agar kehidupan keluarga dalam rumah tangga senantiasa dalam keadaan baik dan tenteram ${ }^{15}$.

Kadang juga motif ayam jantan dilambangkan sebagai matahari. Lambang tersebut mengandung makna atau pesan bahwa setiap pagi menjelang matahari ter- 
bit, ayam jantan selalu berkokok, menandakan pagi hari telah tiba dan matahari segera terbit ${ }^{16}$. Selain itu, ayam jantan juga dipandang sebagai lambang kekuatan, keberanian dan kesabaran. Ketiga hal ini merupakan unsur kehidupan yang mesti diteladani. Penempatan hiasan ini pada puncak bubungan rumah dimaksud untuk mendapatkan berkah dari para dewa dan leluhur.

\section{(b) Motif Hias Kepala Kerbau}

Selain penggunaan motif hias ayam jantan, motif hias kepala kerbau (ulu tedong) juga menjadi obyek dalam penerapan seni hias anjong istana Bugis. Kerbau dalam kehidupan suku Bugis merupakan hewan yang sering digunakan dalam kegiatan pertanian dan perkebunan. Di samping itu, kerbau juga dianggap sebagai simbol status seseorang. Ini berarti semakin banyak kerbau yang dimiliki seseorang, maka dia kaya dan memiliki status sosial yang tinggi.

Orang Bugis sudah mengenal kerbau sebagai binatang ternak sudah sejak lama. Pada masa tersebut, kerbau bagi suku Bugis sangat dipuja karena dipandang sebagai binatang keramat. Dengan demikian, tidak mengherankan jika kerbau baik secara utuh maupun bagian-bagian (tanduk, kepala dan lain-lain) sering ditampilkan dalam seni hias.

Kerbau bagi suku Bugis merupakan lambang kekayaan, kemakmuran dan status sosial. Selain itu, bagi suku Bugis yang mempercayai adanya roh nenek moyang, kerbau dipandang sebagai kendaraan roh bagi orang yang sudah meninggal. Dalam konsep dualisme atau sistem perbedaan dua bagian, misalnya atas-bawah, baik-buruk, langit-bumi, dan sebagainya. Berkaitan dengan hal tersebut kerbau termasuk yang ada di bagian bumi.
Oleh karena itu, motif seni hias dengan motif kerbau, banyak dijumpai dalam berbagai bentuk. Dalam penerapannya, jarang ditemui pengunaan motif ini dalam wujudnya yang realis, namun telah melewati proses penggayaan, teknik stilasi, dan penyederhanaan bentuk. Hal ini sejalan dengan kecendrungan menempuh jalan pintas membuat motif yang lebih sederhana. Selanjutnya motif hias kerbau ini dibuat dalam bentuk saling menyilang saja, sehingga bentuk aslinya hilang. Akan tetapi tetap memberikan simbol sebagai tanduk kepala kerbau. Hal ini juga tidak terlepas dari pengaruh masuknya agama Islam di Sulawesi Selatan sekitar abad ke 16-17, di mana dalam ajaran Islam disebutkan bahwa Alquran tidak pernah melakukan penghadiran realistis dan naturalistik terhadap alam, baik dalam karya sastra, musik, kaligrafi, pola hias, maupun arsitektur ${ }^{17}$.

Motif ini menjadi pola hias khas bagi suku Bugis dan hanya ditempatkan pada anjong (mahkota atap) dan sesuai dengan konsep kosmologi/mistis suku Bugis. Motif kerbau ini menjadi pelindung dari kekuatan jahat dan pengusir roh jahat, juga sebagai kendaraan roh orang yang telah meninggal.

Penempatan hiasan ini pada puncak bubungan rumah dimaksudkan sebagai perhormatan kepada dewa boting langi' dan kekuatan untuk menolak bala ${ }^{18}$. Motif ini juga bermakna dorongan untuk memperoleh rezeki untuk mensejahterakan keluarga sehingga derajat sosialnya dapat terangkat di tengah masyarakat ${ }^{19}$.

\section{(c) Motif Hias Ular Naga}

Ular naga mempunyai tempat sendiri dalam khazanah seni hias Indonesia. Motif ini ditemukan sepanjang masa. Motif hias ini terdapat di berbagai daerah Nusan- 


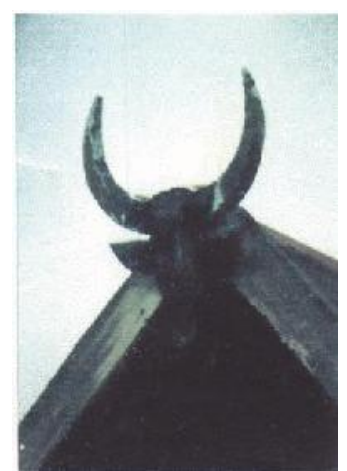

Gambar 115. Motif kepala kerbau yang terdapat pada bubungan rumah Bugis. (Foto :Pangeran Paita, Sidrap 2011)

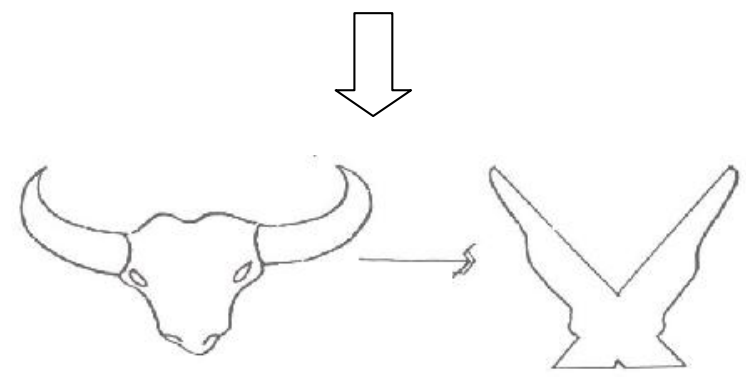

Gambar 116. Proses penyederhanaan motif hias Kepala Kerbau yang biasa ditempatkan pada bubungan istana raja Bugis. (Gambar: Pangeran Paita, Sidrap 2011)

tara, baik sebagai bentuk perlambangan maupun sebagai hiasan. Oleh karena itu, motif hiasan ini sudah lama dikenal, sudah pasti ia lebih tua dari zaman Hindu di Indonesia ${ }^{20}$.

Beberapa kerajaan di Asia Tenggara, rajanya merasa memiliki ikatan kekerabatan yang erat dengan ular naga, dan mereka merasakan mendapat kekuatan dari makhluk tersebut. Itulah sebabnya motif ular naga bagi suku Bugis, di samping sebagai lambang dunia atas, juga mewakili dunia bawah sebagai lambang pemilik kekayaan yang sewaktu-waktu dapat dimintai pertolongannya oleh manusia ${ }^{21}$.

Oleh karena itu, dalam tradisi pendirian istana atau keraton pada beberapa kerajaan di nusantara, motif ular naga diterapkan pada beberapa bagian istana. Pada rumah Bugis, motif ular naga biasanya di- tempatkan pada bagian puncak bubungan rumah serta pada bagian tangga.

Menurut kepercayaan suku Bugis, ular naga hidupnya di langit dan merupakan perlambang kekuatan yang maha dahsyat. Seni hias naga ini mempunyai makna yang bersumber kepada perlambangan. Dalam konsep kosmologis/mitologi suku Bugis, demikian dahsyatnya kekuatan yang dimiliki naga sehingga jika naga itu marah atau murka, maka matahari dan bulan pun akan ditelannya. Jika ini terjadi, maka timbullah gerhana bulan atau matahari. Oleh karena kepercayaan yang begitu besar terhadap kekuatan yang dimiliki oleh ular naga, maka setiap kegiatan harus mendapat restu dan perlindungannya. Jadi naga sebagai dewa dan dipersonifikasikan sebagai dewa boting langi'.

Selanjutnya yang mengetahui kemauan dari naga itu adalah para sanro (saman/ dukun). Dukun dapat menentukan ke arah mana naga itu menghadap sehingga tidak bertentangan dengan kegiatan yang dilakukan oleh seseorang. Dengan demikian, kekuatan dahsyat yang dimiliki oleh naga itu dapat dijadikan perlindungan. Ular naga dalam perlambangan dunia bawah bermakna perempuan. Hal ini sering dikaitkan dengan indo pare (Dewi Sri). Binatang ular naga dalam perlambangannya disamakan dengan bumi. Hiasan anjong pada istana Raja Sidenreng merupakan stilasi bentuk naga yang dipadukan dengan untaian bunga parenreng. Simbolisasi ular naga bagi suku Bugis Sidenreng, melambangkan kekuatan dan perlindungan bagi penghuni rumah yang tiada tandingannya.

\section{(d)Motif Hias Bunga Parenreng}

Pola tumbuh-tumbuhan dalam seni hias Bugis digambarkan dalam bentuk bunga 
menjalar. Bunga atau pohon ini dianggap sebagai lambang dari pohon hidup yang menguasai dunia seperti yang terdapat pada beberapa suku di Indonesia ${ }^{22}$.

Motif bunga ini dalam konsep kosmologis suku Bugis disebut motif bunga parenreng yang mempunyai arti bunga yang menarik. Di samping hidupnya melata dan menjalar kemana-mana seperti tidak ada putus-putusnya.

Bentuk bunga parenreng dalam penggunaannya bermakna sebagai reski yang tak ada putus-putusnya seperti menjalarnya bunga parenreng tersebut. Selain itu, bunga parenreng bermakna sebagai lambang kesuburan dan kemakmuran.

Tanaman bunga yang terbentuk atas susunan daun atau bunga sulur-suluran menurut van der Hoop. Di zaman prasejarah di Indonesia tidak ditemukan adanya perhiasan tanaman, tetapi di zaman kemudian, yakni Hindu, perhiasan ini menjadi umum dan menjadi bagian yang penting terutama dalam ornamentik Indonesia ${ }^{23}$.

Namun demikian, perlu dikemukakan pendapat beberapa ahli yang mengatakan bahwa pengaruh Hindu di Sulawesi Selatan sangat sedikit dibanding di pulau Jawa dan Bali $^{24}$. Dengan demikian, munculnya motif hias bunga parenreng (motif sulur-suluran) yang diduga mendapat pengaruh Hindu dalam khazanah seni hias Bugis, dianggap sebagai 'penyimpangan' dari sekian banyak motif hias yang ada pada rumah Bugis. Dengan demikan, pengaruh Hindu yang sedikit itu mungkin saja ada dalam seni hias Bugis, khususnya pada rumah Bugis Sulawesi Selatan.

Hiasan anjong pada istana raja Wajo memadukan motif hias bunga parenreng, kaligrafi arab dengan bentuk mahkota sebagai simbol kerajaan. Motif hias ini sebagai simbol bahwa penghuni rumah tersebut adalah seorang bangsawan dan beragama Islam.

Pada bagian list plant dihiasi dengan motif bunga setangkup diselingi bentuk sulapa eppa dalam untaian bunga-bungaan yang bermakna kesuburan, keharmonisan dan keselarasan. Bentuk bunga parenreng dalam penerapannya selalu tampil dalam bentuknya yang natural tanpa adanya stilasi bentuk.

Motif yang terdapat pada istana raja Wajo, disebut juga belo-belo timpalaja bermakna kesuburan dengan hiasan untaian bunga dan bentuk sulapa eppa. Penggunaan tiga tingkatan timpalaja (timpanon), menandakan yang punya rumah adalah seorang bangsawan tinggi. Makin banyak tingkatan pada timpalajanya, makin tinggi pula derajat kebangsawanan yang punya rumah $^{25}$.

\section{(e) Seni Hias Bulan dan Bintang}

Motif hias bulan-bintang, penerapannya ditemukan pada istana Raja Bone, Saoraja Wajo, dan Saoraja Sidenreng. Secara keseluruhan, penempatan motif bulan-bintang menambah estetika istana raja Bugis. Dengan demikian, selain berfungsi untuk memperindah bangunan, motif hias ini juga mengandung makna simbol tertentu yang dipercaya oleh suku Bugis.

Motif seni hias ini biasanya dikombinasikan dengan bentuk bintang lima yang terletak di tengah bulan sabit dan bunga parenreng. Posisi hiasan mengikuti arah hadap rumah, biasanya diterapkan pada bagian depan dan belakang puncak bubungan dan pada bagian dinding istana.

Motif bulan dan bintang biasa disebut uleng lolo (bulan yang baru terbit). Menurut pandangan kosmologis suku Bugis, pola hias ini melambangkan tempat asal nenek moyang suku Bugis dan lam- 
bang kehidupan. Menurut kepercayaan orang Bugis, nenek moyangnya berasal dari langit. Tomanurung adalah dewa yang diturunkan dari langit tempat yang tinggi yang sengaja diutus oleh Dewata Seuwae ke bumi untuk memerintah.

Tomanurung dianggap sebagai manusia yang luar biasa yang memiliki kesaktian. Ia dapat memerintah dengan baik karena ia merupakan keturunan dewa.

\section{b. Makna Seni Hias Istana Bagian Tengah}

Motif seni hias yang muncul pada bagian tengah atau badan rumah (Alle Bola), pada umumnya bermotif flora seperti bunga parenreng, pucuk rebung, atau jantung pisang, dan bermotif geometris. Sedangkan yang berasal dari alam, yakni motif ombak-ombak dan bintang. Seni hias tersebut biasanya ditempatkan pada tudung angin, lubang angin, dinding, dan jendela.

\section{1) Belo-Belo Cirik-Ciring}

Nama hiasan ini Belo-belo Cirik-Ciring ditemukan di istana Raja Bone yang berarti seni hias yang dikenakan pada papan penahan ujung atap agar tetap lurus. Motif hias ini bermakna simbolis yang diambil dari untaian daun pisang. Motif ini terbentuk dari perpaduan daun pisang dengan pelepahnya mengikuti bentuk ujung daun pisang yang terbuka lebar berjejer. Di antara ujungnya terdapat bunga pisang yang sedang mekar.

Tanaman pisang bagi suku Bugis, di samping memiliki manfaat yang cukup banyak, misalkan daunnya sebagai pembungkus makanan, buahnya dapat dimakan, dan akarnya dapat dijadikan obat. Paling istimewa, pucuk pohon pisang ti- dak akan pernah berhenti tumbuh walau telah ditebang. Dalam istilah orang Bugis disebut maddaung maccolli'. Makna simbolisnya adalah kemakmuran, rejeki yang datang tidak henti-hentinya seperti pohon pisang walau telah ditebang, tetap pucuk baru akan muncul.

\section{b) Motif Pucuk Rebung (Cobo'-Cobo')}

Bentuk hiasan yang menyerupai ujung tombak atau segi tiga runcing, biasa juga disebut belo-belo patteppo barakapu, yang melambangkan kekuasaan ${ }^{26}$. Bentuknya berasal dari hiasan geometris berbentuk tumpal. Hiasan yang memiliki kemiripan yang ditemukan pada motif sarung sutera Bugis (Lipa' Sabbe), tetapi pada persamaan fisik beda pada makna dan fungsinya. Motif ini memiliki fungsi estetis untuk memperindah istana. Pandangan suku Bugis, motif seni hias pucuk rebung (cobo'-cobo') bermakna kesuburan dan kebahagiaan.

Di Kabupaten Sidenreng Rappang, motif hias ini disebut curek pucu'. Bentuknya yang simetris melambangkan keharmonisan dan kesetaraan. Fungsi hiasan ini sebagai penahan air hujan dan penahan dari terik sinar matahari, juga untuk memperindah bentuk timpalaja (timpanon).

\section{c) Motif Hias Bua Pandang (Buah Nenas)}

Motif Buah nenas (bua pandang) bagi orang Bugis adalah tanaman yang dianggap memiliki keistimewaan. Buah ini di samping memiliki rasa yang manis, buahnya selalu menghadap ke atas. Pada bagian samping buah, keluar daun yang mirip orang yang sementara berdoa, sehingga tanaman ini oleh orang Bugis disebutnya tanaman mamminasa (tanaman yang selalu berdoa untuk kebaikan). Motif hias tersebut diterapkan pada istana bermakna agar penghuni rumah rezekinya 
selalu bertambah banyak, sebagaimana nenas yang buahnya selalu tumbuh mengarah ke atas.

\section{d) Motif Hias Gambara Bunga (Motif}

Hias Bunga dan Daun)

Motif ini bermakna simbol kehidupan. Arah untaian daun berputar ke kanan. Di tengahnya terdapat simbol delapan penjuru angin yang menyerupai roda atau bunga yang sedang mekar. Bagian atas dan bawah bunga yang sedang kuncup. Keseluruhan motif hias ini kemungkinan besar untuk pengejaran nilai estetis semata, agar segenap penghuni merasa senang dan betah di rumah.

\section{e) Motif Belo-Belo Tellongeng}

Motif Belo-Belo Tellongeng yang terdapat pada istana Raja Wajo berfungsi sebagai jalan keluar masuknya udara ke dalam rumah agar tidak sumpek dan panas. Bentuknya berupa untaian bunga yang saling terjalin satu sama lainnya. Jumlah baris hiasannya selalu ganjil $(3,5,7,11)$, dan selalu dihitung mulai dari hidup, mati, hidup. Maksudnya agar penghuni rumah selalu dalam keadaan sehat. Selain itu, penghuni rumah akan selalu hidup dinamis dan akan selalu berusaha memenuhi keinginan dan kebutuhannya dan tak akan merasa cukup atau genap ${ }^{27}$.

Dari segi bentuk dan penggunaan jumlah teralis, menurut Kahar Wahid, jikalau teralisnya berbentuk kecil dan jumlahnya banyak (7, 9, 11 buah), menunjukkan pemilik rumah adalah seorang bangsawan tinggi. Motif hias ini sebagai simbol kemakmuran $^{28}$.

Pada bagian badan istana raja Wajo, seni hias yang diterapkan, salah satunya terdapat pada bagian jendela istana yang biasa juga disebut Belo-Belo Tellongeng.
Motif ini dikenakan pada ventilasi jendela, bagian atas dan bawah yang menerapkan motif bunga parenreng dalam bentuk yang setangkup. Seni hias ini bermakna kesuburan dan keselarasan hidup bagi penghuni istana. Seni hias tersebut, di samping memiliki makna simbolis, juga berfungsi untuk memperindah bangunan istana.

\section{f) Motif Hias Belo-belo Renring}

Motif hias ini dipahatkan pada dinding istana raja Bone. Hiasan didominasi untaian motif bunga Parenreng pada papan les pinggir bidang segi empat, baik yang tegak lurus maupun yang datar. Pada bidang segi empat ada sulur-suluran yang merambat pada bagian kiri dan kanan bidang dari bawah ke atas dan dari atas ke bawah, sulur-suluran bertemunya di tengah-tengah bidang. Motif ini dimaknai ini dimaknai sebagai simbol keharmonisan antara laki dan perempuan (suamiistri) dalam satu keluarga ${ }^{29}$.

Motif hias belo-belo renring, di samping memiliki makna simbol tertentu yang bersifat filosofis juga berfungsi sebagai pencapaian nilai estetis yang dapat mempengaruhi penghuni rumah. Penghuni rumah akan selalu merasa senang dan memiliki gairah dalam bekerja ${ }^{30}$.

\section{g) Motif Hias Bunga Sulapa eppa}

Motif hias Bunga sulapa eppa terdapat di Kabupaten Bone, berupa sulur-suluran yang mengisi bidang berbentuk persegi. Pokok dalam motif hias ini adalah bunganya yang berbentuk segi empat. Konsep suku Bugis, asal manusia berasal dari empat unsur yakni tanah, air, api, dan angin. Keempat unsur inilah yang merupakan pembentuk manusia sempurna. Bila dikaitkan dengan empat penjuru mata angin, maka manusia hidup pada 
satu tempat dengan empat penjuru: utara, timur, selatan, dan barat.

Seorang raja yang menjadi pemimpin dan memerintah, harus memiliki kecerdasan (amaccang), kekayaan (asongireng), keberanian (barani), dan keadilan (adele). Seorang raja yang selalu memiliki sifat-sifat tersebut, maka ia akan dicintai oleh rakyatnya. Keempat hal di atas, juga senantiasa menjadi pegangan dalam kehidupan orang-orang Bugis. Banyak sekali pesan-pesan yang yang terdapat dalam lontarak ${ }^{31}$ yang merupakan pedoman hidup bagi orang Bugis, dan diimplementasikan pada bentuk seni hias seperti bunga sulapa eppa, wala suji, tiang rumah, dan bentuk rumah ${ }^{32}$.

\section{h) Motif Hias Rapang Bunga Tabbakka}

Rapang Bunga Tabbakka atau motif bunga yang sedang mekar di temukan di Kabupaten Wajo, merupakan simbol kesejahteraan dan kesenangan. Bentuknya yang setangkup bermakna kesepadanan, keharmonisan dan kedamaian. Hiasan tersebut, disamping memiliki makna simbol juga memiliki fungsi memperindah istana.

\section{i) Motif Hias Belo-belo Sudu' (Hiasan Sudut)}

Motif hias ini menggambarkan untaian daun-daunan sebagai simbol kesuburan. Bentuknya setangkup bunga yang juga melambangkan keharmonisan suami istri atau ayah dan ibu. Motif hias BeloBelo Sudu', di samping memiliki makna simbolis juga berfungsi estetis.

Motif hias sejenis ditemukan pada istana raja Sidenreng di Kabupaten Sidenreng Rappang dikenakan pada bagian ujung balok yang tergantung. Bentuknya yang menjalar sebagai simbol kesuburan.

\section{j) Motif Hias Belo-belo Massulapa (Hias-} an Pesegi)

Hiasan Belo-belo Massulapa terdapat pada istana raja Bone Kabupaten Bone ini merupakan motif persegi yang bersumber dari dasar bunga sulapa eppa, dipadu dengan sulur-suluran berbentuk pilin berganda. Motif tersebut merupakan pengembangan dari bentuk Sulapa eppa yang merupakan dasar filosofi bagi orang Bugis.

\section{k) Motif Hias Bintang}

Motif hias ini merupakan kombinasi bentuk bintang enam sebagai dasar dan bintang lima di atasnya. Bintang di kalangan orang Bugis dianggap sebagai pedoman waktu, baik bagi petani, nelayan, dan untuk masyarakat umum. Motif hias bintang, di samping memiliki makna simbolis juga memiliki fungsi untuk memperindah istana.

\section{c. Makna Seni Hias Istana Bagian Bawah (kaki rumah)}

\section{1) Motif Hias Ular Naga dipadukan Motif Hias Bunga Parenreng}

Nama motif hias ini belo-belo addeneng. Motif ini bersumber dari tumbuhtumbuhan yang dipadukan dengan motif ular naga. Hiasan yang ditempatkan pada tangga istana Raja Bone menempatkan motif flora yang diberi nama motif bunga parenreng. Makna perlambangan hiasan yang ada pada tangga ini adalah rezeki yang datang tidak akan henti-hentinya. Di samping itu, bunga parenreng bermakna kehidupan, kekayaan, serta kemakmuran.

Hiasan ini ditempatkan pada bagian bawah rumah, dengan harapan apapun yang datang dari bawah merupakan berkah yang berasal dari Dewa Uwae. Di sam- 
ping itu, motif ini mengandung kekuatan magis yang dapat melindungi penghuni istana dari hal-hal yang tidak baik. Di samping motif bunga parenreng, motif lain yang tampil dalam bagian tangga ini adalah ular naga. Menurut pandangan suku Bugis, naga digunakan sebagai penolak bahaya yang mengancam keselamatan dari arwah yang meninggal. Di samping itu, motif ini juga sebagai penambah estetika pada rumah Bugis Sulawesi Selatan.

Menurut Dg. Mabbara, seni hias ini berfungsi sebagai doa bagi penghuni rumah agar senantiasa sejahtera dan bahagia. Motif ular naga ditempatkan pada bagian tangga istana dengan harapan dapat menangkal kesialan dan malapetaka bagi para penghuni. Sedangkan motif bunga parenreng disimbolkan sebagai rezki bagi penghuni istana yang tak putus-putusnya $^{33}$. Motif hias ini, di samping memiliki makna simbolis, juga berfungsi untuk memperindah istana.

\section{2) Motif Hias Ulu Addeneng}

Motif hias yang terdapat pada bagian kepala tangga. Motif yang bersumber dari bentuk daun sawi (kolu) dengan dedaunan yang lebar. Motif hias ulu addeneng dalam pandangan suku Bugis bermakna kesuburan dan kesejahteraan.

Adapun fungsi mengapa ragam hias ini ditempatkan pada bagian kepala tangga adalah sebagai doa atau harapan bagi siapa saja yang menaiki tangga tersebut, rezekinya akan bertambah. Di samping itu, hiasan ini juga berfungsi untuk memperindah $^{34}$.

\section{3) Motif Hias Belo-Belo Cappa Pattolo}

Motif hias ini ditempatkan pada ujung balok penyanggah tiang istana. Motif hias Belo-belo Cappa Pattolo yang terdapat pada istana Raja Wajo dan Sidenreng sebagai simbol kemewahan dan harga diri. Di samping memiliki makna simbolis, hiasan ini juga memiliki fungsi untuk memperindah bentuk istana secara keseluruhan.

Motif hias Belo-belo Cappa Arateng, kalau dikenakan pada balok arateng (balok penyanggah rumah bagian atas). Biasanya, hiasan ini ditempatkan pada empat penjuru mata angin sesuai sisi bangunan istana dengan berdasar pada filosofi sulapa eppa.

\section{4) Motif Hias Rapang Daung Kolu (Sawi)}

Hiasan ini biasa juga disebut Belo-Belo Sapana, motif hias ini bersumber dari tumbuh-tumbuhan daun kol (sawi) yang sangat subur, yang bermakna kesejahteraan dan kemakmuran. Hiasan ini berfungsi sebagai penghias ujung balok. Biasanya dikenakan pada bagian bangunan yang mudah dilihat orang, seperti pada ujung tangga atau ujung balok (pattolo ataupun arateng).

Jenis hiasan ini sama dengan yang dikenakan pada tangga bagian atas pada istana Raja Wajo. Bedanya pada penempatan hiasan pada bagian bawah tangga disebut juga belo-belo sapana, karena hanya dikenakan pada tangga khusus untuk rumah atau istana raja atau bangsawan tinggi.

Motif hias ini berfungsi estetis dan untuk memperkuat konstruksi tangga pada bagian tengah. Menurut Kahar Wahid, tangga yang memiliki tiga induk tangga hanya dimiliki oleh istana raja atau bangsawan tinggi. Jika tangga tersebut terbuat dari bambu disebut sapana. Sebutan sapana digunakan juga untuk tangga yang memiliki tiga induk tangga yang membedakannya dengan tangga biasa ${ }^{35}$.

\section{5) Motif Hias Uso Massusuang}

Merupakan motif hias yang bersumber dari bentuk jantung pisang yang ber- 
susun. Bentuknya persegi empat yang mengandung makna filosofi sulapa eppa. Motif hias seperti ini biasanya dikenakan pada bagian ujung balok yang tergantung, seperti pada ragam hias nenas.

Pucuk pohon pisang tidak akan pernah berhenti tumbuh walau telah ditebang. Dalam istilah orang Bugis disebut maddaung maccolli. Makna simbolisnya adalah kemakmuran, rejeki yang datang tidak henti-hentinya seperti pohon pisang walau telah ditebang, tetap pucuk baru akan muncul.

Dari rangkaian motif seni hias yang tervisualisasikan di atas, dapat dijelaskan bahwa terdapat berbagai macam dan bentuk motif hias yang ditampilkan. Ragam hias yang ditampilkan sangat bervariasi dan umumnya terdiri atas motif dan struktur hias yang memang sering diterapkan oleh suku Bugis dan berorientasi pada bentuk-bentuk tumbuhan sekitar. Selain itu, terdapat juga motif dan struktur bentuk hias yang merupakan pengaruh dari budaya Dong-son, Chou Tua, Jawa, Islam serta budaya lainnya. Misalnya, masuknya agama Islam membawa warna baru dalam berkesenian di tanah Bugis, hal ini juga mempengaruhi seni hias yang diciptakan. Kesenian yang berkembang pada masa Islam telah memberikan corak dan karakter tersendiri dan memiliki ciri tersendiri bagi perkembangan kebudayaan selanjutnya. Pengaruh Islam pada seni hias Bugis tampak kombinasi motif bunga parenreng dengan tulisan kaligrafi Arab 'Muhammad', juga pada kombinasi antara motif sulapa eppa dengan bentuk bintang lima. Dari keanekaragaman seni hias tersebut telah melahirkan seni hias khas Bugis di daerah ini.

\section{PENUTUP}

Bila mencermati motif dan struktur pola tumbuh-tumbuhan yang terdapat pada seni hias yang ada, maka diyakini bahwa sumber ide dan gagasan motif dan pola hiasnya terinspirasi dari daerah setempat. Masyarakat Bugis memanfaatkan bentuk-bentuk tumbuhan yang ada di alam sekitar sebagai sumber ide dalam mewujudkan seni hias yang diinginkan.

Lingkungan alam sekitar telah menyediakan begitu banyak sumber inspirasi untuk mewujudkan gagasan dan ketersediaan bahan yang dapat digunakan oleh masyarakat. Sementara budaya lokal (local genius) memberikan arah pada suku Bugis bagaimana menyikapi semuanya. Manusia memiliki kecendrungan berekspresi dan berkarya seni dengan berorientasi pada lingkungan dan alam sekitarnya.

Motif hias bentuk tumbuh-tumbuhan dalam implementasinya diterapkan pada berbagai media, disusun sedemikian rupa membentuk bidang bidang yang harmonis, dan umumnya diwujudkan dalam bentuk simetris. Sementara penggunaan garis dan bidang tegas, lugas, seperti penerapan pada motif berbentuk sulapa eppa (belah ketupat), swastika, dan bidang terukur lainnya. Biasanya disusun dalam bentuk ragam geometrik. Penerapan ragam geometrik tampak pada dinding, list plank, dan jendela.

Beberapa motif seni hias yang ada, sangat sulit untuk diberikan nama. Tidak semua nara sumber mengetahui dan memahami motif hias yang ditemukan. Sebagian besar nara sumber menyebutkan nama motif seni hias berdasarkan letak atau posisi motif tersebut berada, misalkan motif belo-belo renring (hiasan dinding) karena motif hiasnya ditem- 
patkan pada dinding Saoraja, atau motif belo-belo addeneng karena hiasannya ditempatkan pada bagian tangga istana.

Beberapa nara sumber menyebutkan nama motif seni hias yang ada sesuai dengan bentuk fisik yang terlihat dan telah akrab dengan penggunaan motif tersebut. Misalnya motif hias ulu tedong (kepala Kerbau), motif manuk (ayam jantan), naga, bunga parenreng (sulur-suluran), bua pandang (Buah Nenas), pucuk rebung, sulapa eppa wala suji (segi empat beah ketupat), dan lain sebagainya.

Beberapa seni hias yang diterapkan pada istana, tampak jelas mendapat pengaruh dari luar. Misalnya pengaruh budaya Islam yang terlihat pada motif hias pada istana raja Bone, berbentuk bintang atau pada anjong atau mahkota atap istana raja Wajo, terdapat kaligrafi bertuliskan 'Muhammad' dikombinasikan dengan sulur-suluran serta bentuk mahkota. Menariknya dalam perjalanan kebudayaan Bugis, terutama dalam penggunaan seni hias pada istana raja, beberapa motif hias yang ada masih mendapat pengaruh dari gaya Dongson, gaya Chou Tua. Namun setelah kedatangan Islam, gaya dan motif yang sudah ada sebelumnya masih tetap dipertahankan, namun bentuk distilasi atau digayakan agar tidak menyerupai figur yang ada di alam, terutama hewan atau binatang.

\section{CATATAN AKHIR}

${ }^{1}$ Koentjaraningrat, Kebudayaan, Mentalitet dan Pembangunan (Jakarta: Gramedia Pustaka Utama, 2004), 5-6.

${ }^{2}$ Koentjaraningrat, 7 .

${ }^{3}$ Eko Budihardjo, Rumah sebagai Warisan Budaya (Jakarta: Djambatan,1997), 6.
${ }^{4}$ R. P. Soejono, "Rumah Tradisional", dalam Gunawan Tjahjono, Rumah (Jakarta: Buku Antar Bangsa untuk Grolier International Inc, 2002), 10

${ }^{5}$ Clifford Geerz, The Interpretation of Culture (New York: Basic Books,1973), 9..

${ }^{6}$ Geertz, 12.

${ }^{7}$ Hans-Georg Gadamer, Kebenaran dan Metode, Pengantar Filsafat Hermeneutika (Yogyakarta: Pustaka Pelajar, 2004), 161-166. Lihat juga Hans-Georg Gadamer, Philosophical Hermeneutics, dalam E. Sumaryono, Hermeneutik: Sebuah Metode Filsafat (Yogyakarta: Kanisius, 1999), 84

${ }^{8}$ Victor Turner, The Forest of Simbols: Aspecs of' Ndembu Ritual (London: Cornell Paperback, Cornell University Press, 1967), 50-51.

${ }^{9}$ Kuntowijoyo, Metodologi Sejarah, edisi kedua (Yogyakarta: Tiara Wacana Yogya, 2003), 43.

${ }^{10}$ Kuntowijoyo, 43-44.

${ }^{11}$ Leo Kleden, “Teks, Cerita, Transformasi Kreatif", dalam Kalam: Jurnal Kebudayaan, Edisi 10, 1997), 34-35.

${ }^{12}$ Kuntowijoyo, 44.

${ }^{13}$ Matthew B. Miles dan A. Michael Huberman, Analisis Data Kualitatif: Buku Sumber tentang Metode-Metode Baru, terjemahan Tjetjep R. Rohidi (Jakarta: Universitas Indonesia Press, 1992), 20.

${ }^{14}$ Wiwiek P. Yusuf, Sahriah, dan Endang. Upacara Tradisional (Upacara Kematian) Daerah Sulawesi Selatan (Ujung Pandang: Departemen Pendidikan dan Kebudayaan, 1992), 23.

${ }^{15}$ Abdul Samad, wawancara, Kabupaten Sidrap, 2011.

${ }^{16}$ Daeng Mabbara, wawancara, Kabupaten Bone, 2011.

${ }^{17}$ Ismail Raji al-Fariqi, Seni Tauhid-Esensi an Ekspersi Estetika Islam ( Yogyakarta: Yayasan Bentang Budaya, 1999), 8-9, 14.

${ }^{18}$ Abdul Samad, wawancara. Kabupaten Sidrap, 2011.

${ }^{19}$ Daeng Mabbara, wawancara. Kabupaten Bone, 2011.

${ }^{20}$ A..N.J. Th a Th. van der Hoop, Indonesische Sier Motieven (Bandung;s' Gravenhage, N.V. Uitgeverij W. van Hoeve 1949), 206.

${ }^{21}$ Abdul Samad, wawancara, 2011

${ }^{22}$ Van der Hoop, 100-278. 
${ }^{23}$ Van der Hoop, 232.

${ }^{24}$ John Miksic, "Tahap Berburu dan Meramu di Indonesia Timur" dalam John Miksic. Sejarah Awal (Jakarta: Buku Antar Bangsa untuk Grolier International. Inc, 2002), 33-34, 56.

${ }^{25} \mathrm{~A}$. Kahar Wahid. Wawancara, 2011.

${ }^{26}$ Kahar Wahid, wawancara, 22 April 2011.

${ }^{27}$ Dg. Mabbara. Wawancara, Kabupaten Bone, 2011.

${ }^{28}$ Kahar Wahid. Wawancara, 2011.

${ }^{29}$ Dg. Mambara. Wawancara, 2011

${ }^{30}$ Kahar Wahid. Wawancara, 2011.

${ }^{31}$ Selain berarti tulisan. Juga berarti kitab (pustaka). Kata Lontarak berasal dari kata lontar, semacam pohon yang banyak tumbuh di Sulawesi Selatan. Daun lontar dijadikan tempat menuliskan riwayat-riwayat, kisah, catatan, peristiwa, silsilah, dan petuah-petuah. Aksara lontarak diciptakan oleh Syahbandar kerajaan Gowa yang bernama Daeng Pamatte, berasal dari Lakiung, Gowa Sulawesi Selatan kira-kira pada abad ke 16, dan banyak mendapat pengaruh dari pola bunyi dan aksara Sansekerta. Kemudian oleh orang-orang Bugis ditambahkan dengan huruf (aksara) mpa, nre, ngke, karena dalam pengucapannya, huruf tersebut tidak terdapat dalam bahasa Makassar.

${ }^{32}$ Kahar Wahid. Wawancara, 2011.

${ }^{33}$ Dg. Mabbara. Wawancara, 2011

${ }^{34}$ Kahar Wahid, wawancara, 2011.

${ }^{35}$ Kahar Wahid, Wawancara, 2011.

\section{DAFTAR PUSTAKA}

Al-Fariqi, Ismail Raji

1999 Seni Tauhid-Esensi an Ekspersi Estetika Islam. Yogyakarta: Yayasan Bentang Budaya.

Budihardjo, Eko

1997 Rumah sebagai Warisan Budaya. Jakarta: Djambatan.

Gadamer, Hans-Georg

2004 Kebenaran dan Metode, Pengantar Filsafat Hermeneutika. Yogyakarta:

Pustaka Pelajar.
Gadamer- Hans-Georg

1999 Philosophical Hermeneutics, dalam

E. Sumaryono, Hermeneutik: Sebuah

Metode Filsafat. Yogyakarta: Kanisius.

Geerz, Clifford

1973 The Interpretation of Culture. New York: Basic Books.

Hoop, A.N.J. Th a Th. van der

1949 Indonesische Sier Motieven. Bandung;s' Gravenhage, N.V. Uitgeverij W. van Hoeve.

Kleden, Leo

1997 “Teks, Cerita, Transformasi Kreatif", dalam Kalam: Jurnal Kebudayaan, Edisi 10.

Koentjaraningrat

2004 Kebudayaan, Mentalitet dan Pembangunan. Jakarta: Gramedia Pustaka Utama.

Kuntowijoyo

2003 Metodologi Sejarah, edisi kedua. Yogyakarta: Tiara Wacana Yogya.

Miksic, John

2002 “Tahap Berburu dan Meramu di Indonesia Timur" dalam John Miksic. Sejarah Awal. Jakarta: Buku Antar Bangsa untuk Grolier International. Inc.

Miles, Matthew B. dan A. Michael Huberman 1992 Analisis Data Kualitatif: Buku Sumber tentang Metode-Metode Baru, terjemahan Tjetjep R. Rohidi. Jakarta: Universitas Indonesia Press. 
Soejono, R. P

2002. "Rumah Tradisional", dalam Gunawan Tjahjono, Rumah. Jakarta: Buku Antar Bangsa untuk Grolier International Inc.

Turner, Victor

1967 The Forest of Simbols: Aspecs of Ndembu Ritual: London: Cornell Paperback, Cornell University Press.

Yusuf, Wiwiek P, Sahriah, dan Endang 1992 Upacara Tradisional (Upacara Kematian) Daerah Sulawesi Selatan. Ujung Pandang: Departemen Pendidikan dan Kebudayaan.

\section{NARA SUMBER:}

Abdul Kahar Wahid, wawancara, Makassar, 07 Agustus 2011.

Abdul Samad, wawancara, Kabupaten Sidrap, 11 September 2011.

Dg. Mabbara, wawancara, Kabupaten Bone, 17 September 2011. 